\title{
Взгляд на национализм - терминологические вопросы и эволюция понятия
}

\begin{abstract}
Аркадиуш Меллер
Corresponding author: Университет Казимежа Вельки в Быдгоще, ул. Яна Кароля Ходкевича 30, г. Быдгощ, 85-064, Польша, доктор наук, е-таil: ameller23@gmail.com, ORCID: 0000-0001-9301-3350
\end{abstract}

Received: August 2, 2020 | Revised: August 20, 2020 | Accepted: August 31, 2020

DOI: $10.33445 /$ sds.2020.10.4.8

\begin{abstract}
Аннотация
Национализм - это одно из тех социальных явлений, которое вызывает ряд сомнений и недоразумений. Его часто обвиняют во всех злах, во главе с ответственностью за осуществление этнических чисток. В то же время среди исследователей нет единого мнения о значении основных признаков, определяющих национализм. Столкнувшись С проблемой определения того, что такое национализм, мы часто сталкиваемся с антиномическими высказываниями друг другу. Ввиду такого положения дел возникает вопрос, существует ли только один универсально применимый тип национализма, или же было бы более уместно утверждать, что существует множество националистических настроений. Цель приведенной ниже статьи - попытаться обсудить различные противоположные друг другу подходы к национализму, проследить его эволюцию и найти ответ на вопрос, может ли национализм, как того хотят некоторые авторы, быть определен как некая форма идеологии?
\end{abstract}

Ключевые слова: национализм, социальное явление, эволюция.

\section{Постановка проблеми}

Сложность в точном определении того, что такое национализм, его многомерности заключается в том, что этот термин вызывает ряд эмоций и у исследователей. Некоторые из них, не колеблясь, называют национализм как "убогой интеллектуально и программно», «эмоциональной», «полной антиномий», "банальной» (Durska, A., 2007) идеологией. Также нет недостатка В том, чтобы отождествлять национализм с нацизмом (Jedlicki J., 1997) или указывать на существование предполагаемых связей, связывающих расизм с национализмом: «связь между идеей расового превосходства и националистической мотивацией является прямой - разница обычно сводится к разной расстановке акцентов и использованию разных аргументов» (Юстиньский, 2000). Уничижительное выражение национализма сопровождаются утверждениями, определяющими национализм как идеологию
(Дзюбка, К.), основными признаками которой должны быть: шовинизм, ксенофобия, стремление к территориальному экспансионизму, ориентация в политической практике на принцип национального эгоизма, который предписывает рассматривать другие народы с презрением и враждебностью (Дзюбка, К.). Национализм иногда связывают с феноменом идолопоклонства или отцовства. Такую позицию разделяет, в частности, А. Дурска, которая утверждает, что «... категория нации как высшая ценность является основным ориентиром и предметом интереса для идеологов национализма. Служение нации должно быть самым важным или даже единственным мотивом для действий». Такое отношение принято, среди прочего А. Дурска, который утверждает, что: “... категория нации как высшей ценности является главным ориентиром и интересом идеологов 
национализма. Служение нации должно быть самым важным или даже единственным мотивом для действий» (Durska A., 2007). Из представленного способа трактования национализма, разумеется, только краткого складывается впечатление, что существует только один тип национализма, обозначение которого должно совпадать с признаками, указанными выше. Является ли такое утверждение, к которому склонны стремиться авторы представленных отличий, обоснованным? Или, возможно, мы имеем дело со многими националистическими идеями?

\section{Изложение основного материала}

\section{Национализм или национализмы?}

Статический подход к определению сущности национализма кажется нам неуместным, поскольку мы не видим эволюции концепции, которую проходили интересующие нас понятия. Этот подход, как нам кажется, игнорирует также тот факт, что сам национализм имеет множество оттенков.

Следует отметить, что национализм, как и любое другое социально-политическое явление, имеет как радикальный (экстремальный), так и умеренный облик (Tarasiewicz P., 2003). В случае умеренного национализма мы имеем дело с более или менее сознательным чувством солидарности с нашей собственной нацией и ее культурой, при этом это не идолопоклонство. В то же время эта форма национализма не принимает форму коллективизма, потому что она часто имеет личную основу, которая гарантирует уважение к индивидуальному измерению человеческой личности, что является результатом принятия и включения христианских этических принципов в его аксиологическую систему. Поэтому национализм в вышеуказанной форме не стремится доминировать и контролировать другие нации и обычно лишен экспансионизма. Этот тип национализма не противоречит патриотизму, и между ними даже существует тесная взаимосвязь, потому что, как отмечает В. Васютинский, «вы не можете любить свою родину, не любя нацию, или любить нацию, не любя родину». Примат интересов нации и примат интересов страны одинаковы» (Wasiutyński W., 1980).

В свою очередь, экстремальный (агрессивный) национализм характеризуется: шовинизмом, обожествлением собственной нации, обесцениванием других народов; следование извращенному принципу национального эгоизма (Balicki Z., 1902; Dmowski R., 1903; Grott B., 1993) ${ }^{1}$ в политической практике, который, признавая благо своего народа как высшую и единственную цель человеческой жизни, требует подчинения всей человеческой деятельности для достижения этого блага (без учета персоналистической концепции человеческой природы); такое отношение также сопровождается феноменом градации народов, согласно которому собственная нация находится на ее вершине; еще один, органично связанный с такой формой национализма, является принцип социального дарвинизма, который проповедует необходимость постоянной борьбы между народами (Tarasiewicz Р., 2003).

Можно легко заметить, насколько неверно понимается утверждение о существовании единой, универсально действующей модели национализма. Очевидно, что между этими категориями националистических идей существуют значительные различия, и ошибочно отождествлять национализм только с одной (искаженной) версией.

\section{Национализм в отношении к религии}

\footnotetext{
${ }^{1}$ Сам принцип национального эгоизма, провозглашенный в Польше, в том числе Зигмунтом Балицким и Романом Дмовским, в кратчайшие сроки означал необходимость руководствоваться в общественной жизни стремлением к достижению благ собственного народа, проявлять солидарность с его интересами, стремиться к тому, чтобы национальные интересы не были

в том числе, необходимость самосовершенствования личности на благо высшей формы общественной жизни, каковой является нация. Национальный эгоизм противопоставляется космополитическому, просвещенному универсализму, провозглашающему примат абстрактных идей (“гуманности”, “прав человека”) над конкретным, исторически существующим сообществом, таким как нация.
} подчинены интересам других народов. Такое отношение означает, 
Одним из чрезвычайно важных качеств дифференциации внутреннего национализма, который является своего рода камнем испытаний, является отношение национализма к религиозным вопросам. Вышеизложенный тезис находит обоснование в утверждении В. Гротта, который отмечает, что «одним из наиболее важных критериев, которые должны использоваться для классификации учений о националистических движениях является их отношение к религии, выражающие их ценности и философские системы» (Grott B., 2001).

Разделение на национализм умеренный и экстремальный показывает совпадение с типологией национализма, предложенной Б. Гроттом, который, разделяя национализм согласно «отношениям между ними и религией» (Grott B., 2006), указывает на то, что национализм, основанный на христианских принципах, показывает сходство с умеренным национализмом. Однако агрессивная форма национализма остается идентичной тому, что и вышеупомянутый исследователь и В. Васютинский обозначает неоязыческим /языческим национализмом (Grott B., 2006).

Важной чертой христианского (в том числе католического) национализма является отказ от абсолютного признания нации, что является определяющей чертой языческого национализма в пользу Бога. Смысл идеологического теистического каркаса является отказ от политического макиавеллизма в пользу христианской этики, которая заключается в нормализации отношений не только между людьми, но и между народами, что явно ставит данную категорию националистических идей в оппозицию против шовинизма, столь характерному для национализма, который отвергает христианские ценности в пользу обожествления национального сообщества. Естественным следствием сделанных выше положений является отказ от религиозного индеферентизма и всех его проявлений в форме либерализма, социализма, материализма и т. д. (Grott B., 2006).

Неоязыческий национализм, находящийся в оппозиции к католическому национализму, приобретает все те черты, о которых говорилось при описании агрессивного национализма. Следует, однако, добавить, что прилагательное, определяющее значение этой формы национализма, может быть несколько вводящим в заблуждение, поскольку оно может свидетельствовать о том, что сторонники этой идеи пытаются воскресить в буквальном смысле старые языческие культы, как отмечает Б. Гротт неоязычники не воспринимают древние убеждения буквально и не стремятся их полностью воссоздать (хотя, как и в случае с немецким нацизмом, некоторые попытки (Goodrick N., 2001; Haack F. W., 1999; Okraska R., 2001) были предприняты B этом направлении, но Задруга, активно действующая во времена ॥ Республики Польша, чтобы строго восстановить язычество, т. е. в форме обновления этого типа культов, не придавала значения противопоставлению динамичного, виталистического, волюнтаристского славянского язычества якобы пассивному, ослабляющему духу нации католицизму. В концепциях Яна Стахнюка (Grott B., 2003; Tenże,1999; Majchrowski J., 1996; Tomasiewicz J., 2000) и его сторонников неоязычество должно было быть формой выражения стремления к глубокой индустриализации страны В материалистическом духе. Следует также подчеркнуть, что Задруга отвергает шовинизм, поэтому он не включен В приведенную выше классификацию), но суть вопроса заключается в «новом этносе определенного характера, который не учитывает универсальные ценности».

По мнению националистов-неоязычников, каждый народ должен обладать собственной отдельной этикой, отражающей его якобы «неповторимый дух и служение по отношению к его интересам» (Grott B., 1999). Аналогичного мнения придерживается видающийся польский деятель и национальный (националистический) идеолог В. Васитутиньский, который, характеризуя вышеупомянутое идеологическое направление утверждает, что его принцип заключается в признании благополучия нации и ее интересов важнейшим законом и 


\begin{tabular}{lcll}
\hline критерием & всех & моральных & оценок \\
(Wasiutyński & W., & 1980). C & учетом
\end{tabular}
вышеизложенного становится очевидным, что такой характер приобрел как уже упомянутый нацизм, так и, например, открытый шовинистический и геноцидный украинский национализм, представленный Организацией украинских националистов, цели и основы создания которой были представлены в работе Михновского «Самостоятельная Украина» и Д. Донцова «Национализм» (Komański H., Siekierka S., 2003; Poliszczuk W., 1998; Dunin O., 1974; Masłowskyj W., 2001).

Промежуточной формой между католическим и языческим национализмом является национализм, который для обоснования представляемых идей черпает их из светских концепций. Она характеризуется религиозным безразличием, поскольку рассматривает «религию и церкви только как реальный факт в общественно-политической жизни без учета в своих представлениях и доктринах требований католицизма или других христианских конфессий» (Grott B., 1994). Эта категория национализма часто инструментализирует религию в соответствии с ее собственными ожиданиями и интересами, не заботясь о сохранении религиозной ортодоксальности, в результате чего она может вступать в противоречие с Magisterium sanctam Ecclesiam. Также в аксиологической системе вышеуказанной категории национализма нация может занимать ведущее место, заменяя таким образом место Бога (хотя это не является правилом из-за огромного разнообразия внутри этого варианта национализма, который распадается на различные более мелкие или крупные подгруппы, разновидности и т.д., которые могут принимать или отвергать католическую этику) (Grott B., 2006).

Эволюция $\quad$ национализма
экземплификация
многогранности национализма

Более пристальный взгляд на эволюцию национализма демонстрирует, что эта идея могла сочетаться с другими (зачастую даже противоречивыми) идеологиями, доказывая тем самым, что национализм не является отдельной, автономной идеологией.
Национализм вышел на историческую арену, как и большинство современных политических доктрин с началом Французской революции; именно тогда возникла первая форма этой идеи. Ее вспышка как и восстание якобинского национализма связаны с формированием новой концепции нации. Новое, потому что давнее традиционное определение нации, характерное для периода государственной монархии, отличалось отождествлением нации с человекоммонархом, который одновременно выражал свою волю (Wielomski A., 2006). В то же время, что не менее показательно, тогдашнее понятие нации не распространяется на всех жителей государства; мы имеем дело с нацией в политическом смысле, общиной, которая чувствует себя подчиненной Королю (Wielomski A., 2006). Вместе с этим, чувство принадлежности к нации характеризовалось только высшими государствами, в то время как самосознание низших государств определялось, прежде всего, через принадлежность к сообществу верующих, которая не знает границ, т.е. христиан, а также к территориально-профессиональному сообществу (Wielomski A., 2006).

С другой стороны, концепция нации в современном понимании, т. е. сообщество свободных индивидуумов, говорящих на одном языке и с общим культурным кодом противоречит прежнему, традиционному подходу. Современная концепция нации создается вместе с прогрессивной урбанизацией и индустриализацией, которые разрушают государственные и корпоративные связи, определяющие положение личности в обществе. Как отмечает Е. Геллнер, с наступлением модернистского (индустриального) общества, чувство территориальной, профессиональной принадлежности (играющей такую важную роль в процессе самоидентификации в дореволюционный период, так как она представляла собой некую посредническую инстанцию между индивидуумом и сообществом, отождествленной с правителем) невероятно слаба из-за создания специальных профессиональных групп, состав которых не является постоянным 
или постоянным (Gellner E., 1991). Отсутствие чувства стабильности, устойчивости, укорененности ведет к необходимости поиска адекватной «формулы своей коллективной идентичности». Подрыв индустриализацией старых социальных структур означает, что «между индивидом и сообществом посредничает очень мало связующих, реальных организаций» (Szacki J., 1997), поэтому «становится особенно важным, что начинает ассоциироваться (что в прошлом редко случалось) и с государственной, и с культурной границей. В результате эрозии всех подгрупп и давления, оказываемого на общую культуру, на первый план выходит нация» (Gellner E., 1991).

В то же время возрождение национализма (XVIII век) является выражением того, что Хосе Ортега и Гассет называют «массовым восстанием», а Юлий Эвола - «революцией изгоев», а именно, как отмечает Адам Веломский, национализм стал «идеологией вновь образованных групп, которые пытаются оправдать свои претензии на признание, престиж или власть» (Wielomski А., 2006). Национализм стал выражением интересов так называемого третьего государства, то есть достаточно большой по своим размерам социальной группы весьма разнообразного характера (поскольку в нее входили буржуазия, крестьяне, банкиры, промышленники и т.д.), которая получала все большее экономическое преимущество над другими социальными государствами, но практически не имела политического влияния. Вот почему были выдвинуты обвинения против других социальных групп в представлении только определенных интересов, а не общих интересов, то есть всей нации (тогда нация была отождествлена с людьми, то есть с третьим государством), и что привилегированные группы являются иностранными (носят иностранный характер) по отношению к «национальным, родным» слоям общества (Wielomski A., 2006).

Чрезвычайно важную роль в становлении современной нации сыграло создание националистами - интеллектуалами всей национальной культуры и истории, что позволило создать однородную группу, внутренне целостную и имеющую общие цели, среди которых ведущее положение занимало желание расформировать тогдашнюю элиту и занять ее место.

Как отмечает Э. Геллнер, «национализм создает народ, а не наоборот». Конечно, он использует исторически более раннюю, исторически унаследованную пролиферацию культур (а также культурных ресурсов), однако, это чрезвычайно избирательное использование. Чаще всего происходят радикальные преобразования. Возрождаются мертвые языки, появляются традиции, возрождается вымышленная первобытная чистота (Gellner Е., 1991). Ощущение собственной культурной самобытности обогатило те социальные группы, к которым национализм был адресован в своем первоначальном виде, потому что, как подчеркивает А. Веломский, «благодаря национализму те, кто до сих пор был никем, внезапно становятся или, по крайней мере, чувствуют себя всем - они нация». Вместо маргинального общества, они теперь его сущность, лучшая, самая патриотичная и «национальная» часть» (Wielomski A., 2006).

Революционный характер первоначальной формы национализма, также известного как Рисорджименто (Szacki J., 1997) или якобинский национализм (Wielomski A., 2003), был действительно «коперниканским переворотом» в области легитимности власти. Этот тип национализма, основанный на контрактной теории общественного договора Дж. Руссо, отрицает традиционную теорию легитимности, основанную на принципе божественного происхождения всей власти в пользу народа, ставшего сувереном, от которого правители должны были получить обоснование для своей власти. Очевидно, что отказ от теистической теории легитимности власти подразумевал секуляризм, антикатолицизм, который проявился В репрессиях, направленных против Церкви (которые в случае революции 1789 года приняли форму убийств духовенства, попыток создания национально-патриотической «французской церкви», нарушившей связь со 
Святым Престолом, требование от Духовенства принести присягу на так называемой гражданской конституции, ввести выборы относительно назначения епископских и пресвитерианских должностей, на которых также могли претендовать атеисты, неверные, вводить новые светские праздники и календарь, в котором нет места для воскресенья и т. д.). Символическим аспектом становления республики стало осквернение (разрушение) царских гробниц в Сент-Денисе и убийство революционерами Людовика XVI и его супруги (австрийки по происхождению) Марии Антуанетты. Акт цареубийства был задуман Якобиным, чтобы окончательно разорвать все связи со старым режимом, на руинах которого должен был быть создан новый республиканский порядок. Примечательно, что оправданием этого преступного деяния послужило то, что королевской чете приписали измену во имя иностранных (заграничных) интересов. Личность монарха стала своего рода синонимом отчужденности, космополитизма и враждебности по отношению к народу (с которыми была отождествлена нация), якобы необоснованно присваивавшему первоначальный суверенитет народа (Wielomski A., 2003).

Еще одной особенностью якобинского революционного национализма был крайний эгалитаризм (в революционном издании был представлен как объявление вне закона или «врагами народа» лиц, представляющих старый режим каким-либо образом), который иногда принимал абсурдные формы, подобные тому, что описал выдающийся австрийский писатель, историк Эрик фон Кюнельт-Леддихн: «Падение Робеспьера (...) сорвало не только план по сносу всех башен церквей как "недемократических», поскольку они были выше других зданий, но и его намерению одеть всех французов и француженок в одну униформу» (Von Kuehnelt Е., 2007). Якобинский эгалитаризм, конечно же, ненавидел разнообразие и поэтому стремился устранить все (включая все провинциальные и языковые различия, столь характерные для дореволюционной Франции (Von Kuehnelt E.,
2007)), что не соответствовало принятому ими образу мира, согласно которому «другое нельзя было рассматривать как «равное». Врагом считался тот, «кто выделялся из толпы по языку, внешности, акценту, наличию собственности, образованию и поведению. Он должен был стать похожим, и если это было невозможно по какой-то причине, он должен был уйти или умереть» (Von Kuehnelt E., 2007).

Якобинский национализм отождествлялся с Французской Республикой, которая должна была воплотить основные революционные идеи, такие как: контрактуализм, превосходство нации, эгалитаризм, гуманизм, демократизм, и, в результате, те соседние страны, которые пытались восстановить порядок в мятежной Франции, были признаны реакционными (Wielomski A.).

Похожие по характеру французского якобинского национализма имели антилегитимное течение итальянского движения Рисорджименто (представленное такими революционными теоретиками, как Ж. Маццини, Ж. Феррари, К. Каттанео (Handelsman M., 1923; Żywczyński M., 1971)) и националистические (национально-освободительные) движения «Весны наций», которые характеризовались антимонархизмом, секуляризмом, эгалитаризмом, антитрадиционализмом, демократизмом, проявляющимся в признании нации - народа как единственного суверена.

Указанные формы национализма, в центре внимания которых было признание национального суверенитета и продвижение принципа «национальности», предоставившего отдельным народам право на самоопределение (что совпадает с предложенным Э. Геллнером определением национализма, согласно которому он является политическим принципом, который гласит, что «политические образования должны совпадать с национальными образованиями» (Gellner E., 1991) ,т. е. давая каждой нации право на владение своим собственным государством) иногда называемого националитаризмом (это понятие было введено Рене Йоханнетом для того, чтобы отличать антидемократический, 
традиционалистский национализм от эгалитарного национализма), который может быть в форме вышеупомянутого демолиберального национализма, а также племенно расового национализма (или, по определению Б. Гротта, неоязычного национализма), принимающего, как и якобинизм, принцип суверенитета народа (Bartyzel J., 2004).

Качественный прорыв в развитии национализма произошел на рубеже XIX и XX веков, когда произошел разрыв национализма с просветительно-рационалистическими корнями. Именно тогда, как отмечает $A$. Веломский, идея нации была объединена с традиционными, контрреволюционными элементами и разочарованием народа в отношении «национальных» правительств, которые завоевали власть в отдельных европейских странах после 1848 года, становились все более инерционными, плутократическими элитами власти (например, ведущие политики III Республики избавились от планов восстановления утраченной после 1870 года Эльзаса и Лотарингии) (Wielomski A., 2006). Точкой прорыва в создании целостного национализма стало так называемые дело Дрейфуса, которое началось в 1894 году и касалось обвинения французского офицера еврейского происхождения, капитана в проведении шпионской операции в пользу немецкой разведки (как выяснилось позднее, обвинение было ложным), который в итоге был удален из армии, понижен в должности и приговорен к тюремному заключению. Французское общественное мнение на пике «скандала», то есть в 1896-1906-х годах четко разделилось на сторонников обвиняемого (эта позиция была представлена светскими и республиканскими кругами, обвинявшими армию и церковь в организации так называемого скандала Дрейфуса) и его оппонентов (выходцев из католических и правых кругов). Именно тогда якобинские эпигоны полностью отождествили республику со светским государством, над которым нависла угроза контрреволюции (отождествляемая армией и Церковью) (Kucharczyk G., 2006). В ответ на все эти события в 1898 году Моисе Пуджу и Анри Вожуа учредили $\begin{array}{lcr}\text { Французский } & \text { комитет действий и } \\ \text { акцентировали } & \text { на необходимости } & \text { введения } \\ \text { авторитарного } & \text { правительства, которое }\end{array}$ ссылалось бы на идеи и принципы античного режима, однако, некоторые активисты комитета по-прежнему ссылались на республиканские идеи. Лишь только контакты с Чарльзом Мауррасом сделали Action Francaise идеологическим и политическим движением как националистического, так и монархического характера (Bartyzel J., 2006).

Таким образом, национализм, выросший из просветительских идей, приобретает консервативные черты (становится антидемократическим, антиегалитарным, провозглашает первенство трансцендентности над имманентизмом). Интегральный национализм (представленный, в частности, франкизмом (Wielomski A., 2006), саларизмом, лузитанским интегрализмом (Bartyzel J., 2006), вышеупомянутым Action Francaise (Maurras Ch., 2003), польским национальным движением, особенно его частью, представленной так называемым «молодым»), становится антиномией национализма, поскольку он отвергает одну из его конституционных особенностей, которая является признанием суверенитета нации. Как отмечает Дж. Бартизел, «структурно националистический принцип не является национальным и демократическим, а государственным и чаще всего монархическим или, по крайней мере (как в Барресе) авторитарным и элитарным». Для национализма сувереном не является народ, только государство, олицетворяемое «главой», (...)». В доктрине национализма нация не является, и не может быть, владыкой и потому, что он представляет общину многих поколений, включающую, помимо живущих поколения, уже минувшие, и те, которые только родятся; голоса предков и нерожденных потомков не могут быть «отсчитаны», а «взвешены». Для националиста нация - это наследие истории, которое нельзя растрачивать впустую, это «сообщество предназначения» (Bartyzel J., 2004). Поэтому интегральные националисты рассматривают народ не как выражение национальных интересов (желающих выразить свою волю 
путем голосования), а как своего представителя, «который заботится об этом интересе, не будучи избранным народом; отсюда и предрасположенность (..) к монархии (Мауррас), авторитарноиерархической системе (Дмовски, Баррес, Коррадини)» (Wielomski A.).

Следует отметить, что польское национальное движение за свою более чем столетнюю историю, как и французский национализм, прошло через все вышеперечисленные формы национализма. На начальном этапе польское национальное движение (период деятельности Польской лиги, Национальной лиги, ДемократичноНациональной партии и идеологического творчества Яна Людвика Поплавского, Зигмунта Балицкого и первых произведений Романа Дмовского, которые приходились на рубеж XIX и XX веков) было идеологическим движением, сильно погруженным в сферу своего времени, то есть т. е. позитивизм, «идеи и концепции находились под влиянием светских взглядов и не коррелировали с взглядами Церкви на сферы их жизни, которых они касались» (Grott В., 1994). Католицизм рассматривался как один из многих социальные фактов, которые лагерь национальной демократии обязательно должен был учитывать в своих концепциях. Можно сделать вывод, что на первая фаза создания идеологических основ польского национального движения оценка Церкви была интерпретирована с точки зрения ее полезности для реализации национальных интересов, которые заключались в сохранении господства над христианской религией (выражением такого отношения была формулировка понятия «две этики: национальная и христианская»). которые должны были касаться двух различных сфер человеческой жизни. Согласно этой концепции, христианская этика должна была регулировать отношения между людьми, в то время как национальная этика должна была регулировать отношения между человеком и обществом и между народами причем в случае конфликта между ними национальная этика должна была сохранить приоритет). Следует, однако, подчеркнуть, что национальная демократия, выстраивая свое мировоззрение на светских принципах (часто позитивистского характера), не боролась с Церковью, рассматривая ее лишь как некое социальное явление, тесно связанное с народом (Grott B., 1994; Nacjonalizm polski, 2003).

Изменение отношения национального лагеря к религиозным вопросам произошло в межвоенный период. Именно тогда произошел отход от религиозного индеферентизма к полному принятию учения Церкви и христианской этики. Отступление от позитивистских идей началось с публикации в 1927 году брошюры Романа Дмовского «Церковь, нация и государство». Отныне главным лозунгом польского национального движения была фраза Р. Дмовского: «Католицизм не является дополнением к польскости, определенным образом, окрашивающим его, но в значительной степени являющимся его сущностью. Попытка отделить католицизм от польскости, отделение народа от религии и церкви - это разрушение самой сущности нации» (Dmowski R., 1964). В отличие от первой фазы своего развития, национальный лагерь полностью адаптировал к своей полити-ческой программе принципы католицизма, которые проявились, среди прочего, в признании Церкви в качестве просветителя народов, и в качестве своего долга национальный лагерь (особенно поколение «молодых») признал борьбу за установление католических принципов в общественной жизни, которая проявилась, среди прочего, в концепции моно-идеальности (великим пропагандистом которой был Адам Добошинский) или в Католическом Государстве Польской Нации (Nowosad W., 1939; Poradowski М. 1997). Проявлением влияния католицизма на идеологическую форму национального лагеря стало включение элементов томистической мысли в политическую мысль о национальной демократии (лучшим примером может служить работа А. Добошинского «Национальная экономика», а также огромная популярность в национальной среде произведения М. Бердяева «Новое 
средневековье», которое было переведено национально - радикальным активистом М. Реуттом) (Grott В., 2001) ... Отказ от религиозного идеферентизма в пользу католицизма также сопровождался отходом от националита-ризма, что проявилось, в частности, в отказ от "духа XIX века» (Malatyński А., 1925) или идей, основанных французской революцией во главе этнической концепции нации и идеи национального суверенитета. Однако следует отметить, что трансформация польского националитаризма в целостный (христианский) касалась только одной ветви национального лагеря, т.е. «молодых националистов», тогда как «парламентский лексикон» Национальной демократии (по словам Й. Гертиха (Giertych J., 1938)) основывался на националитарных позициях.

\section{Выводы}

В свете вышеизложенных фактов становится очевидным, что национализм, вопреки иногда расхожему мнению, не является однородным по своему характеру и утверждение о том, что существует лишь один вид национализма, является неприемлемым. Национализм, в силу выраженного отношения к религии, эгалитаризму и т.д., распадается на несколько типов. Поэтому его можно сочетать с различными идеологиями, политическими доктринами, часто противо-речивыми. Национализм может быть крайне эгалитарным, левым, как и в случае с якобинством или контрреволюционным правым нацизмом, как и в случае с интегральным национализмом. Легкость, с которой национализм вступает в различные идеологические союзы, можно объяснить и тем, что это не форма политической идеологии, а лишь просто, как отмечает А. Веломский, «национализация других идеологий» (Wielomski A., Nacjonalizm). Без всестороннего видения мира его нельзя рассматривать как идеологию. Это форма уточнения других доктрин, с которыми она вступает в более или менее длительные союзы. Похоже, что ответ на вопрос о том, что же такое национализм, дает В. Васютиньский, утверждая, что национализм «означает выдвижение национальных интересов на первый план» (Wasiutyński W., 1980); Я. М. Боченьский (Bocheński J. M., Szkice), придерживается аналогичного мнения. Таким образом, национализм является императивом, который требует учета всех политических действий с точки зрения интересов и благосостояния нации, тогда как само определение нации, а также определение того, как должны реализовываться эти национальные интересы и какое место нация должна занимать в аксиологической системе, отличается и зависит в основном от отношения данной категории национализма к религиозным вопросам.

\section{Список использованных источников}

Bachoud A., Franco, Warszawa 2000

Balicki Z., Egoizm narodowy wobec etyki, Lwów 1902

Bartyzel J., "Umierać, ale powoli!". O monarchistycznej i katolickiej kontrrewolucji w krajach romańskich 1815-2000, Wyd. II, Kraków 2006

Bartyzel J., Action Francaise, [w:] Encyklopedia "Białych Plam", t. I, Radom 2000

Bartyzel J., Fatalne nieporozumienie: nacjonalizm czy nacjonalitaryzm?, [w:] "Historia i polityka. Wiek XX. Studia z historii myśli politycznej i idei" 2004, t. I,
Bartyzel J., Frankizm, [w:] Encyklopedia "Białych Plam", t. VI, Radom 2001

Bartyzel J., Nacjonalizm Charlesa Maurrasa, Pro Fide, Rege et Lege, 2000, nr 1 (36)

Bartyzel J., Nacjonalizm chrześcijański w Portugalii, "Pro Fide, Rege et Lege" 2006, nr 2 (55)

Bartyzel J., Salazaryzm, [w:] Encyklopedia "Białych Plam", t. XVI, Radom 2005

Bocheński J. M., Szkice o nacjonalizmie i katolicyzmie polskim, bdm, c. 86.

Chmaj M., Żmigrodzki M., Wprowadzenie do teorii polityki, Lublin 1998 
Dmowski R., Kościót, naród i państwo, Londyn 1964

Dmowski R., Myśli nowoczesnego Polaka, Lwów 1903

Dunin O., Prawda o Ukraińskiej Organizacji Wojskowej, "Zeszyty Historyczne" 1974, № 30

Durska A., Rozdwojona jaźń polskiego nacjonalizmu [w:] pod red. M. Karwata, Problemy polityczne, Warszawa 2007

Eisler J., Od monarchizmu do faszyzmu. Koncepcje polityczno-społeczno prawicy francuskiej 19181940, Warszawa 1987

Giertych J., O wyjście z kryzysu, Warszawa 1938

Gellner E., Narody i nacjonalizm, tł. T. Hołówka, Варшава, 1991, с. 81.

Goodrick-Clark N., Okultystyczne źródła nazizmu. Tajne kulty aryjskie oraz ich wpływ na ideologię nazistowskq 1890-1935, Warszawa 2001

Grott B. (red.), Nacjonalizm czy nacjonalizmy? Funkcja wartości chrześcijańskich, świeckich i neopogańskich $w$ kształtowaniu idei nacjonalistycznych, Kraków 2006

Grott B., Chrześcijańskie i świeckie inspiracje w doktrynach nacjonalizmu polskiego, "Przegląd Humanistyczny" 1994, t. 4

Grott B., Elementy tomizmu jako czynnik normujqcy podstawy ideowe ruchu narodowego $w$ Polsce, [w:] pod red. $\mathrm{M}$. Szulakiewicza, Filozofia i polityka w XX wieku, Kraków 2001

Grott B., Nacjonalizm chrześcijański . Narodowo katolicka formacja ideowa w II Rzeczpospolitej na tle porównawczym, Wyd. III, Krzeszowice 1999

Grott B., Religia, cywilizacja, rozwój. Wokót idei Jana Stachniuka, Kraków 2003

Grott B., Religia, Kościół, etyka w ideach i koncepcjach prawicy polskiej , Kraków 1993

Grott B., Religia, kościół, etyka w ideach $i$ koncepcjach prawicy polskiej. Narodowa Demokracja. Wybór tekstów, Kraków 1993

Haack F. W., Neopoganizm w Niemczech: Powrót Wotana. Religia krwi, ziemi i rasy, Kraków 1999

Handelsman M., Zjednoczenie Włoch, Варшава, 1923

Herbut R., Ideologia[w:] pod red. A. Antoszewskiego i R. Herbuta, Leksykon politologii, Wrocław 2002

Jaskułowski K., Nacjonalizm jako ideologia, "Przegląd Polityczny" 2003, № 2

Jedlicki J., Nacjonalizm, patriotyzm i inicjacja kulturowa, "Znak" 1997, № 3

Justyński J., Historia doktryn polityczno-prawnych, Toruń 2000

Kiciński K., Egoizm i problem zachowań prospołecznych, Warszawa 1978

Komański H., Siekierka S., Ludobójstwo dokonane przez nacjonalistów ukraińskich na Polakach w województwie tarnopolskim 1939-1946, Wrocław 2003

Kowalski K., Święty Tomasz a czasy obecne, Poznań 1935

Kucharczyk G., Kielniq i cyrklem. Laicyzacja Francji w latach 1870-1914, Warszawa 2006

Lynn R., Socjobiologia nacjonalizmu [w:] pod red. B. Szackiej i J. Szackiego, Człowiek zwierze społeczne, Warszawa 1991

Majchrowski J., Szkice z historii polskiej prawicy politycznej lat Drugiej Rzeczpospolitej, Kraków 1986

Malatyński A., Święty Tomasz z Akwinu a obóz narodowy, Warszawa 1925

Masłowskyj W., Z kim i przeciw komu walczyli nacjonaliści ukraińscy w latach II wojny światowej, Wrocław 2001

Maurras Ch., Jestem Rzymianinem, "Pro Fide, Rege et Lege" 2003, nr 1-2 (45)

Nacjonalizm polski, [w:] Encyklopedia "Białych Plam", т. XII, Радом, 2003, с. 249.

Nowosad W., O jednolity poglq̨d na świat, Lwów 1939

Okraska R., W kręgu Odyna i Trygława. Neopoganizm w Polsce i na świecie (zarys problematyki), Biała Podlaska 2001

Poliszczuk W., Integralny nacjonalizm ukraiński jako odmiana faszyzmu, t. 1, Toronto 1998

Poradowski M. ks., Katolickie Państwo Narodu Polskiego, Wrocław 1997

Program Action Francaise, [w:] I. Rusinowa, T. Wituch, Między rewolucjq francuskq a rewolucja październikowq, Warszawa 1980

Prus B., Atamania UPA, Wrocław 1996

Prus B., Stepan Bandera (1909-1959). Symbol zbrodni i okrucieństwa, Wrocław 2004 
Skibiński P., Państwo generała Franco. Ustrój Hiszpanii w latach 1936-1967, Kraków 2003

Skrzyński R., Konserwatyzm. Zarys dziejów filozofii politycznej, Warszawa 1998

Szacki J., O narodzie i nacjonalizmie, "Znak" 1997, № 3

Tarasiewicz P. ks., Nacjonalizm, [w:] Encyklopedia "Białych Plam" t. XII, Radom 2003

Tomasiewicz J., Między faszyzmem a anarchizmem. Nowe idee dla Nowej Ery, Pyskowice 2000

Wasiutyński W., Słownik polityczny, Nowy Jork 1980

Wielomski A., Doktryna EI Caudillaje na tle XIX i XX - wiecznej hiszpańskiej tradycji politycznej, "Studia nad Faszyzmem i Zbrodniami Hitlerowskimi" 1999, t. XXII
Wielomski A., Hiszpania Franco. Źródła i istoty doktryny politycznej, Biała Podlaska 2006

Wielomski A., Tutejszość - naród - Europa. Esej o historycznej roli idei narodowej, "Pro Fide Rege et Lege" 2006, № 2 (55)

Wielomski A., Nacjonalizm,[w:] Encyklopedia..., c. 248-249.

Wilhelmsen F. D., Ideario, ideologia i katolicka filozofia polityczna, tł. J. Bartyzel, Pro Fide, Rege et Lege, 2008, № 1 (60)

Wójcik S., Ideologia [w:] pod red. M. Chmaja i W. Sokoła, Leksykon politologii, Lublin 1999

Von Kuehnelt E. - Leddihn, Ślepy tor. Ideologia i polityka lewicy 1789-1984, tł. M. Gawlik, Вроцлав, 2007, с. 43.

Żywczyński M., Włochy nowożytne, Варшава, 1971.

\title{
Погляд на націоналізм - термінологічні питання і еволюція поняття
}

\author{
Аркадіуш Меллер \\ Університет Казімєжа Вельки в Бидгощі, вул. Яна Кароля Ходкевича 30, м Бидгощ, 85-064, Польща, доктор наук, \\ e-mail: ameller23@gmail.com, ORCID: 0000-0001-9301-3350
}

\begin{abstract}
Анотація
Націоналізм - це одне з тих соціальних явищ, яке викликає ряд сумнівів і непорозумінь. Його часто звинувачують у всіх злах, на чолі з відповідальністю за здійснення етнічних чисток. У той же час серед дослідників немає єдиної думки про значення основних ознак, що визначають націоналізм. Зіткнувшись з проблемою визначення того, що таке націоналізм, ми часто стикаємося з Антиномічна висловлюваннями один одному. 3 огляду на такий стан справ виникає питання, чи існує тільки один універсально застосовний тип націоналізму, або ж було б більш доречно стверджувати, що існує безліч націоналістичних настроїв. Мета наведеної нижче статті - спробувати обговорити різні протилежні одна одній підходи до націоналізму, простежити його еволюцію і знайти відповідь на питання, чи може націоналізм, як того хочуть деякі автори, бути визначений як якась форма ідеології.
\end{abstract}

Ключові слова: национализм, социальное явление, эволюция.

\section{The view to nationalism - terminological issues and the evolution of the concept}

\section{Arkadiusz Meller}

Kazimierz Wielki University in Bydgoszcz, ul. Jan Karol Chodkiewicz 30, Bydgoszcz, 85-064, Poland, Dr. e-mail: ameller23@gmail.com, ORCID: 0000-0001-9301-3350

\begin{abstract}
Nationalism is one of those social phenomena that causes a series of doubts and misunderstandings. He is often accused of all evil, led by responsibility for carrying out ethnic
\end{abstract}


cleansing. At the same time, there is no consensus among researchers about the importance of the main features that determine nationalism. Faced with the problem of determining what nationalism is, we often come across antinomic statements from one another. In view of this state of affairs, the question arises whether there is only one universally applicable type of nationalism, or whether it would be more appropriate to assert that there are many nationalist sentiments. The purpose of the article below is to try to discuss various opposing approaches to nationalism, to trace its evolution and find the answer to the question, can nationalism, as some authors want, be defined as a form of ideology?

Keywords: nationalism, social phenomenon, evolution.

\section{References}

Bachoud A., Franco, Warszawa 2000

Balicki Z., Egoizm narodowy wobec etyki, Lwów 1902

Bartyzel J., "Umierać, ale powoli!". O monarchistycznej i katolickiej kontrrewolucji w krajach romańskich 1815-2000, Wyd. II, Kraków 2006

Bartyzel J., Action Francaise, [w:] Encyklopedia "Białych Plam", t. I, Radom 2000

Bartyzel J., Fatalne nieporozumienie: nacjonalizm czy nacjonalitaryzm?, [w:] "Historia i polityka. Wiek XX. Studia z historii myśli politycznej i idei" 2004, t. I,

Bartyzel J., Frankizm, [w:] Encyklopedia "Białych Plam", t. VI, Radom 2001

Bartyzel J., Nacjonalizm Charlesa Maurrasa, Pro Fide, Rege et Lege, 2000, nr 1 (36)

Bartyzel J., Nacjonalizm chrześcijański w Portugalii, "Pro Fide, Rege et Lege" 2006, nr 2 (55)

Bartyzel J., Salazaryzm, [w:] Encyklopedia "Białych Plam", t. XVI, Radom 2005

Bocheński J. M., Szkice o nacjonalizmie i katolicyzmie polskim, bdm, c. 86.

Chmaj M., Żmigrodzki M., Wprowadzenie do teorii polityki, Lublin 1998

Dmowski R., Kościół, naród i państwo, Londyn 1964

Dmowski R., Myśli nowoczesnego Polaka, Lwów 1903

Dunin O., Prawda o Ukraińskiej Organizacji Wojskowej, "Zeszyty Historyczne" 1974, № 30

Durska A., Rozdwojona jaźń polskiego nacjonalizmu [w:] pod red. M. Karwata, Problemy polityczne, Warszawa 2007

Eisler J., Od monarchizmu do faszyzmu.
Koncepcje polityczno-społeczno prawicy francuskiej 1918-1940, Warszawa 1987

Giertych J., O wyjście z kryzysu, Warszawa 1938

Gellner E., Narody i nacjonalizm, tł. T. Hołówka, Варшава, 1991, с. 81.

Goodrick-Clark N., Okultystyczne źródła nazizmu. Tajne kulty aryjskie oraz ich wpływ na ideologię nazistowskq 1890-1935, Warszawa 2001

Grott B. (red.), Nacjonalizm czy nacjonalizmy? Funkcja wartości chrześcijańskich, świeckich i neopogańskich w kształtowaniu idei nacjonalistycznych, Kraków 2006

Grott B., Chrześcijańskie i świeckie inspiracje w doktrynach nacjonalizmu polskiego, "Przegląd Humanistyczny" 1994, t. 4

Grott B., Elementy tomizmu jako czynnik normujacy podstawy ideowe ruchu narodowego w Polsce, [w:] pod red. M. Szulakiewicza, Filozofia i polityka w XX wieku, Kraków 2001

Grott B., Nacjonalizm chrześcijański . Narodowo - katolicka formacja ideowa w II Rzeczpospolitej na tle porównawczym, Wyd. III, Krzeszowice 1999

Grott B., Religia, cywilizacja, rozwój. Wokół idei Jana Stachniuka, Kraków 2003

Grott B., Religia, Kościót, etyka w ideach $i$ koncepcjach prawicy polskiej, Kraków 1993

Grott B., Religia, kościół, etyka w ideach $i$ koncepcjach prawicy polskiej. Narodowa Demokracja. Wybór tekstów, Kraków 1993

Haack F. W., Neopoganizm w Niemczech: Powrót Wotana. Religia krwi, ziemi i rasy, Kraków 1999

Handelsman M., Zjednoczenie Włoch, Варшава, 1923 
Herbut R., Ideologia[w:] pod red. A. Antoszewskiego i R. Herbuta, Leksykon politologii, Wrocław 2002

Jaskułowski K., Nacjonalizm jako ideologia, "Przegląd Polityczny" 2003, № 2

Jedlicki J., Nacjonalizm, patriotyzm i inicjacja kulturowa, "Znak" 1997, № 3

Justyński J., Historia doktryn politycznoprawnych, Toruń 2000

Kiciński K., Egoizm i problem zachowań prospołecznych, Warszawa 1978

Komański H., Siekierka S., Ludobójstwo dokonane przez nacjonalistów ukraińskich na Polakach w województwie tarnopolskim 1939-1946, Wrocław 2003

Kowalski K., Święty Tomasz a czasy obecne, Poznań 1935

Kucharczyk G., Kielniq i cyrklem. Laicyzacja Francji w latach 1870-1914, Warszawa 2006

Lynn R., Socjobiologia nacjonalizmu [w:] pod red. B. Szackiej i J. Szackiego, Człowiek zwierzę społeczne, Warszawa 1991

Majchrowski J., Szkice z historii polskiej prawicy politycznej lat Drugiej Rzeczpospolitej, Kraków 1986

Malatyński A., Święty Tomasz z Akwinu a obóz narodowy, Warszawa 1925

Masłowskyj W., Z kim i przeciw komu walczyli nacjonaliści ukraińscy w latach II wojny światowej, Wrocław 2001

Maurras Ch., Jestem Rzymianinem, "Pro Fide, Rege et Lege" 2003, nr 1-2 (45)

Nacjonalizm polski, [w:] Encyklopedia "Białych Plam", т. XII, Радом, 2003, с. 249.

Nowosad W., O jednolity pogląd na świat, Lwów 1939

Okraska R., W kręgu Odyna i Trygława. Neopoganizm w Polsce i na świecie (zarys problematyki), Biała Podlaska 2001

Poliszczuk W., Integralny nacjonalizm ukraiński jako odmiana faszyzmu, t. 1, Toronto 1998

Poradowski M. ks., Katolickie Państwo Narodu
Polskiego, Wrocław 1997

Program Action Francaise, [w:] I. Rusinowa, T. Wituch, Między rewolucjq francuskq a rewolucjq październikowq, Warszawa 1980

Prus B., Atamania UPA, Wrocław 1996

Prus B., Stepan Bandera (1909-1959). Symbol zbrodni i okrucieństwa, Wrocław 2004

Skibiński P., Państwo generała Franco. Ustrój Hiszpanii w latach 1936-1967, Kraków 2003

Skrzyński R., Konserwatyzm. Zarys dziejów filozofii politycznej, Warszawa 1998

Szacki J., O narodzie i nacjonalizmie, "Znak" 1997, № 3

Tarasiewicz P. ks., Nacjonalizm, [w:] Encyklopedia "Białych Plam" t. XII, Radom 2003

Tomasiewicz J., Między faszyzmem a anarchizmem. Nowe idee dla Nowej Ery, Pyskowice 2000

Wasiutyński W., Słownik polityczny, Nowy Jork 1980

Wielomski A., Doktryna EI Caudillaje na tle XIX i $X X$ - wiecznej hiszpańskiej tradycji politycznej, "Studia nad Faszyzmem i Zbrodniami Hitlerowskimi" 1999, t. XXII

Wielomski A., Hiszpania Franco. Źródła $i$ istoty doktryny politycznej, Biała Podlaska 2006

Wielomski A., Tutejszość - naród - Europa. Esej o historycznej roli idei narodowej, "Pro Fide Rege et Lege" 2006, № 2 (55)

Wielomski A., Nacjonalizm,[w:] Encyklopedia..., c. 248-249.

Wilhelmsen F. D., Ideario, ideologia i katolicka filozofia polityczna, tł. J. Bartyzel, Pro Fide, Rege et Lege, 2008, № 1 (60)

Wójcik S., Ideologia [w:] pod red. M. Chmaja i W. Sokoła, Leksykon politologii, Lublin 1999

Von Kuehnelt E. - Leddihn, Ślepy tor. Ideologia i polityka lewicy 1789-1984, tł. M. Gawlik, Вроцлав, 2007, с. 43.

Żywczyński M., Włochy nowożytne, Варшава, 1971. 